\title{
INTRODUCTION
}

\section{RECOVERING A REPRESSED PAST}

On February 12, 2013, Ruth Calderon was invited to the dais of the Israeli Knesset to deliver her first speech as a newly-elected member of parliament. ${ }^{1}$ The speech was unlike any given in the history of deliberations in Israel's legislature in that it consisted primarily of her reading and interpreting a Talmudic story. The Talmudic story that Calderon read before the Knesset, first in the original Aramaic and then in Hebrew translation, was, as is typical of these stories, very brief:

Rabbi Rahumi studied under Rava in Mehoza. He would regularly come home to his wife on the eve of Yom Kippur. One day [on the eve of Yom Kippur] the topic [he was studying] drew him in. His wife anticipated him, "He is coming. He is coming." He did not come. She began to grieve. She shed a tear from her eye. He was sitting on a roof. The roof collapsed under him, and he died. (B. Ketubot $62 \mathrm{~b})^{2}$

The story reflects what appears to have been a common practice among rabbinic scholars in Babylonia: to absent themselves from home for long periods of time to study Torah. The author of the story expresses his disapproval of this custom by portraying empathically the emotional stress experienced by Rabbi Rahumi's wife when he was so engaged in Torah study that he forgot to return home for the sacred holiday. The excitement captured in her cry of anticipation, "He is coming. He is coming," dissipated when she realized he had failed to appear. The tear that she shed in response to her profound disappointment was followed immediately by Rabbi Rahumi's death when the roof on which 
he was sitting collapsed, thereby suggesting that in the end he received a well-deserved divine punishment for being so immersed in Torah that he abandoned his wife.

Why, one might ask, would a secular Israeli politician devote her first parliamentary speech to reading and interpreting a selection from the Talmud, a compendium of rabbinic teachings that is at the center of religious Jewish study in yeshivot, but largely ignored by secular Israelis? Furthermore, how could a story critical of a husband who has neglected his wife hundreds of years ago possibly be relevant to the political discourse of Israel's parliament?

In her speech, Calderon signaled to her fellow parliamentarians and to Israelis as a whole that the Talmud was no longer just for religious Israelis and that as a secular Israeli, she advocated studying it outside the confines of the yeshiva. She also made clear that she believed that the Talmud was a relevant source to which one could turn to find solutions to the issues faced by contemporary Israelis. In particular, in her speech she declared that this text could serve as the basis for a discussion of one of the burning political issues of the day: whether the military draft exemption of ultra-Orthodox yeshiva students, dating back to the early years of the State of Israel, should be eliminated or at least modified.

The drafting of ultra-Orthodox yeshiva students had been one of the central political issues during and in the immediate aftermath of the recent election, due largely to two factors: (1) Before the election the Israeli Supreme Court had struck down the yeshiva draft exemption law, which meant that the Knesset was obligated to replace it with a law that did not grant such an exemption. (2) For the first time in many years, no ultra-Orthodox party was included in the governing coalition. Therefore, there was a high likelihood that a new law passed by the Knesset would define the obligation of ultra-Orthodox youths to serve their country in a way that would infuriate that segment of society. The dominant ultra-Orthodox leaders were determined to fight to preserve the draft exemption. Their fierce opposition to eliminating the exemption was due largely to the fact that the ultra-Orthodox feared that if their youths were engaged in either military or civilian national service, they would be exposed to a larger cultural world that might alienate them from the ultra-Orthodox way of life in which they were raised.

Calderon had just been elected to parliament as a member of the Yesh Atid (There is a Future) party, headed by Yair Lapid, which had campaigned on a platform opposed to the fact that ultra-Orthodox Israeli men were allowed by law to engage in extended periods of time studying 
in yeshiva rather than submit to compulsory military service. Israelis of a wide range of political orientations opposed this draft exemption, because it resulted in a high percentage of ultra-Orthodox Israeli men not sharing equally with other Israelis in the responsibility of defending their country. Opponents of the draft exemption also disapproved of the fact that in their full-time yeshiva study, these ultra-Orthodox men did not typically learn skills that would make them employable citizens, causing them and their families to become unnecessarily dependent on government welfare throughout their lives. As Calderon explained in her interpretation of the story, Rabbi Rahumi represents for her the typical ultra-Orthodox Israeli man who, in choosing to devote his entire life to studying Torah, neglects his other human obligations. In the case of Rabbi Rahumi, the neglected party is his wife; in the case of the ultra-Orthodox Israelis, the neglected obligation is military or at least civilian national service and contributing to Israel's economy.

Despite the association she suggested between the story's critique of Rabbi Rahumi and the negative image of the ultra-Orthodox found in Yesh Atid's campaign rhetoric, Calderon was careful not to make use of the story in her speech to excessively fan the flames of political controversy. She magnanimously declared that she learned from the story "that often, in a dispute, both sides are right." ${ }^{3}$ In her reading of the story, both secular Israelis, represented by the wife, and ultra-Orthodox Israelis, represented by Rabbi Rahumi, could be seen as justified when they asserted the value of their way of life and criticized the way of life of their political opponents: "Many times we [secularists] feel like the woman, waiting, serving in the army, doing all the work while others [the ultra-Orthodox] sit on the roof and study Torah; sometimes those others [the ultra-Orthodox] feel that they bear the entire weight of tradition, culture, and Torah on their backs while we [secularists] go to the beach and have fun." ${ }^{4}$ It is only when she could come to appreciate the point of view of both sides, she declared, that she would be able to contribute to finding a solution to this much debated political issue.

Calderon then went on to advocate an alternative to the existing dichotomy between ultra-Orthodox Israelis spending their time studying Torah and not serving in the army and secular Israelis serving in the army and neglecting the study of Torah. In her ideal world, the ultraOrthodox would fulfill some form of national service and the secularists would engage in the study of Torah. "I aspire," she announced, "to bring about a situation in which Torah study is the heritage of all of Israel ... in which all young citizens of Israel assume the responsibility of both 
Torah study and military and civilian national service." In addition to the obvious implication of this statement that she favored a law that would draft ultra-Orthodox young men into the army or some form of civilian national service, she stated explicitly that she would work for financial support from the government for Torah study by secular Israelis equal to that provided to religious Israelis who study in yeshivot.

Calderon's speech evoked a number of strong reactions from Israelis along the political and cultural spectrum. Many responded enthusiastically to this Talmud lesson by a secular Israeli, which publicly broke down the barriers between secularism and religiosity that have dominated Israeli culture for so long. Others, particularly those on the two cultural extremes of ultra-Orthodoxy and secularism, were taken aback by this highly unconventional speech; it confirmed their political anxieties evoked by the establishment of the new government coalition led by Binyamin Netanyahu, of which Yesh Atid became a member in early 2013.

In an article in "Kikar Shabbat," an ultra-Orthodox web site, Yaakov Blau wrote that he believed that Calderon's speech revealed a strong connection between her party's support for proposals to draft ultra-Orthodox men and her encouragement of Torah study from a secular perspective, both of which presented dangers to the future of the ultra-Orthodox way of life. ${ }^{6}$ Blau argued that the speech represented a contemporary revival in Israel of the efforts of the modernizing, antitraditional, late eighteenth and nineteenth-century European Jewish movement known as the Haskalah to destroy traditional Judaism. This new Haskalah, in his opinion, is more dangerous than the original one. It had been clear in its day that the older Haskalah was determined to undermine the authority of the Torah and encourage Jews to assimilate into gentile society, asserted Blau, and so one could understand it as an enemy force to be resisted. While the newer Haskalah is also an enemy of tradition, Blau maintained that it presents itself more ambiguously than the older Haskalah did, and thereby deceives people about its true purpose, causing them to let down their guard. "[It] is not at all like the Jewish Haskalah in Europe," argued Blau, "it understands religious faith and does not reject it out of hand.... [It] does not want to transform us into a nation like all the nations. On the contrary, [it] wants to increase Torah study."7 From Blau's point of view, however, this newer Haskalah resembles the older Haskalah in one way. Just as the older Haskalah resorted to the deceptive use of rabbinical figures (presumably here Blau includes not only Haskalah-oriented traditional rabbis but also rabbis 
identified with Reform Judaism) to seduce Jews away from tradition, so the newer Haskalah makes use of the secular Talmud teacher Calderon (whom he mockingly refers to as a "woman rabbi," which she is not) and two other Yesh Atid members of Knesset, the religious Zionist Rabbi Shai Piron and the ultra-Orthodox Rabbi Dov Lipman, as "fig leaves who use our weapons [i.e. sacred rabbinic texts] ... against us." ${ }^{8}$

On the other end of the political spectrum, secular left-wing journalist Uri Misgav felt threatened by Calderon's speech for a different reason. ${ }^{9}$ For him, the speech confirmed the dangers inherent in the joint participation in the government coalition by the Yesh Atid party, led by Yair Lapid, and the religious Zionist Habayit Heyehudi (The Jewish Home) party, led by Naftali Bennett. Misgav argued in an opinion column in the daily newspaper Haaretz that it is likely, due to this political cooperation between the two parties, that Yair Lapid will sell out the political principles that are so important to his secular supporters. Indeed, he maintained, a significant sign of this selling out can be discerned in Ruth Calderon's speech. The speech, he declared, followed the typical pattern of alliances between the secular and the religious, which he believed always involved the self-denigration of the secular and the compromising of their principles to satisfy the religious. He sarcastically critiqued the "excited song of praise sung with a trembling voice ... [and] the bending of knees" in submission to the values of the religious that he discerned in Calderon's speech. ${ }^{10}$

Misgav then went on to refer to a famous 1952 meeting between a leading ultra-Orthodox rabbi Avraham Yeshayahu Karelitz, known as the Hazon Ish, and then Prime Minister David Ben-Gurion. At this meeting, it was reported, the Hazon Ish had insisted that secular Israelis would have to accommodate the needs of religiously observant Israelis, for just as when a full wagon (which to him represented the religious culture) and an empty wagon (which to him represented the secular culture) meet on the road, the empty wagon should give way to the full wagon. Calderon's speech, in Misgav's opinion, demonstrated the degree to which she agreed with the Hazon Ish's position that secular cultural is "empty," in the sense of worthless, and that religious culture is "full," in the sense of containing much meaning and significance: "Once again the empty wagon accompanied by self-denigration and feelings of inferiority.... Calderon went up on the stage with a book of the Talmud, devoted her speech to a Talmud lesson, and finished it with a prayer." ${ }^{11}$ Even Yair Lapid, the leader of Calderon's party, he noted, indicated his 
willingness to sell out secularism when he "declared recently that his dream is that every child in Israel would learn a page of Talmud along with mathematics." 12

When it comes to compromise between the religious and the secular, complained Misgav, "[t]here is not and never is symmetry." ${ }^{13}$ All attempts at reconciliation between these two cultural orientations, he declared, inevitably end up with the secularists compromising their values, while the religious refuse to compromise theirs. In this speech, he noted, Ruth Calderon had read a selection from a classic work of traditional Jewish religious literature, but he was certain that no religious member of the Knesset would ever read in public from the writings of secular Israeli authors or quote the fiercely anti-religious politician Shulamit Aloni.

It is not surprising that Calderon's attempt to bring together elements of the two extremes of ultra-Orthodoxy and secularism so enraged members of both camps. Political extremes tend to be more comfortable with well-defined positions that clearly distinguish them from those on the opposite end of the political spectrum. They have a vested interest in asserting the purity of their positions, and they feel threatened by the possibility that elements of the opposite position might contaminate their world. Ultra-Orthodox Israelis see themselves as the keepers of the Talmud, and they feel that only the ultra-Orthodox can be trusted to prevent it from being undermined. Secular Israelis see themselves as the keepers of democracy, and they do not trust anyone who studies Talmud to preserve the integrity of Israel's democratic political system. A person such as Ruth Calderon, who seeks to build bridges between the two camps, blurs important differences between them and, from the perspective of extremists, makes it more possible for the other side to take power. From an ultraOrthodox perspective her speech could contribute to the pulling of ultra-Orthodox young men away from traditional faith and practice, and from a secular perspective her speech could contribute to Israel becoming a society dominated by traditional Jewish faith rather than by democratic values.

\section{The Return to the Jewish Bookcase}

Ruth Calderon's controversial speech was not simply the idiosyncratic expression of an individual out of step with accepted political and 
cultural categories. She spoke as one of the leaders of a cultural trend that has been developing in Israel over the past five decades. This trend, which has come to be known as "the return to the Jewish bookcase" (hahazarah la'aron hasefarim hayehudi), has consisted of secular Israeli Jews rediscovering the treasures of the post-biblical Jewish textual tradition that had played only a marginal role in the secular Israeli school curriculum as well as in secular Israeli culture as a whole. I describe this tradition as playing a "marginal role" in secular Israeli education and culture due to the fact that the post-biblical Jewish textual tradition was never fully absent from either the secular Israeli school system or the cultural consciousness of Israeli society. Even Prime Minister David Ben-Gurion, a vocal champion of the secular Zionist rejection of post-biblical Judaism and Diaspora Jewish life, came to see that the lack of an awareness of the entire span of Jewish history in secular Israeli youth was problematic. In 1955, he charged Zalman Aran, the Minister of Education, to develop a Jewish consciousness curriculum for the secular school system. Over the years, various attempts were made to increase the teaching of post-biblical Jewish texts in secular schools. Such efforts, however, never succeeded in fully overcoming the marginalization of the post-biblical textual tradition in secular Israeli culture. ${ }^{14}$

The return to the Jewish bookcase as a significant cultural phenomenon can be said to have begun in the early 1960 s, led by a group of secular Israeli kibbutz intellectuals constituting themselves as "Hug Shedemot." The name of the group signified their association with the journal Shedemot (originally Shedemot lamadrikh), which was established at that time. Among the most notable early members were Avraham (Patchi) Shapira, founding editor of Shedemot, Muki Tsur, and Yariv Ben-Aharon. ${ }^{15}$ Members of this group, who belonged to the second generation of kibbutz members, along with others of their contemporaries, experienced a discomfort with the kibbutz ideology of the generation that had founded the kibbutz movement. Gad Ofaz makes the point that this younger generation's challenge to established kibbutz ideology took place in the context of a perceived decline in the viability of the kibbutz ideology at the time that this second generation was emerging into adulthood: "Many of the beliefs that motivated and sustained the generation of the pioneers collapsed, along with [ideological] struggles and splits. Youths of the second generation felt more and more that a different spiritual basis was needed" to maintain the viability of the kibbutz movement. ${ }^{16}$ 
At the same time, to the extent that the first generation had been able to maintain the influence of kibbutz ideology, the members of the second generation resisted its imposition on their lives. As Alon Gan observes, their resistance followed a pattern that is often repeated in the relationship between revolutionaries and their offspring. "The generation of the parents," writes Gan, "lived the transition from the dream (the utopian vision) to the reality [of the kibbutz] and sought to preserve it by means of ideology. Individuals in the next generation sought to conduct a reverse process from that of their parents: the parents turned utopia into ideology [and] their children sought to break open the lock that preserved the ideology and to form for themselves dreams (utopian visions) of their own. ... they began a journey in search of new dreams."17

As Gad Ofaz observes, one of the central elements of kibbutz ideology challenged by members of the second generation was the rejection of the Diaspora Jewish religious culture and the determination to replace it with a culture in which the main role model was that of a "new Jew, muscle-bound working his land and defending it." ${ }^{18}$ Ofaz explains that the younger generation came to question the anxiety that their parents had felt, which drove them to an extreme hostility toward Diaspora culture: "[The older generation] had a feeling that the Disapora and its religious culture was lurking, as it were, in the corner like a trap for the weak, the less determined, and the overly sensitive." ${ }^{19}$ This rejection of Diaspora religious Jewish culture, writes Ofaz, had a significant effect on the curriculum of secular kibbutz schools. While the Bible, with which they felt an affinity, was taught, "[t]he teaching of Jewish history was cut off at the Bar Kokhba rebellion [in 132-135 CE], and then picked up anew with the emergence of the early Zionists. Thus, the oral Torah [of rabbinic Judaism] was omitted from the curriculum." ${ }^{20}$

Some members of the second generation of kibbutzniks, argues Ofaz, came to believe that this selective, Bible-centered approach to the Jewish cultural heritage left them without the kinds of resources they needed to help them meet the ongoing existential challenges of the immediate pre-State period and of the early years of the State. "The years in which the native-born sons [of the second generation] grew up did not spare them trying moments," writes Ofaz. ${ }^{21}$ "From the time that the first sons born in the kibbutzim grew up, until today, Israel has never experienced calm or peace. Its sons have found themselves in the constant tension of struggling for their very existence."22 A culture that limited itself to the Bible as its main source did not, Ofaz argues, provide 
them with the resources to face these existential challenges: "The giving up of all the cultural assets that were collected during thousands of years of challenges in which the people of Israel persisted meant that [this generation had to] stand and come to terms [with its existence] completely naked [in a spiritual sense]."23 One of the most important potential roles of the post-biblical tradition for members of this new generation was that it could provide a conceptual framework in which to grant meaning to the self-sacrifice to which they were called in the defense of their country. Members of this younger generation, writes Ofaz, "who were aroused to ask about the meaning of national existence and its value in relationship to the life of the individual, were amazed at the strength of persistence that drove the people of Israel during the generations." ${ }^{24}$ Ofaz quotes Eli Alon, a kibbutz poet of that generation: "I feel a great hunger to contemplate the nature of this faith for which Jews were ready to die for the sake of the continuity of generations." 25 This is why, Alon has written, he felt driven to retrieve the wisdom of the Jewish tradition that had been excised from the secular education he and his peers received: "We are cut off from Judaism and from its answers ... years of education to disparage the Diaspora have succeeded in severing us from it and from its culture in which we might perhaps have found an answer to our existential questions." ${ }^{26}$

In addition, for members of this second generation of kibbutzniks, the study of the entire history of Jewish sources was seen as a necessary process to achieve a much needed Jewish cultural renewal. As Yariv BenAharon puts it, "If you want to be who you are, you want to renew life from within, and you want to reveal the hidden forces of inner renewal ... you cannot dismiss the heritage of the past. You have to come to terms with it. You have to draw from it. You have to create from within it."27

Alon Gan points out that initially, Hug Shedemot played a marginal role in kibbutz society, advocating rebellious ideas that were subversive of the cultural status quo. "Shedemot and the group that solidified around it," observes Gan, "were like secret agents who undermined the behavior code of native-born Israelis, while seeking ways to form a spiritual identity that would be an alternative to that of the generation of the fathers." 28 As Gan sees it, the tense period leading up to the Six-Day War in 1967 and Israel's sweeping victory in that war opened up many more secondgeneration kibbutzniks to seeking the kinds of alternative cultural paths advocated by Hug Shedemot. This became very evident, Gan notes, when members of Hug Shedemot engaged in a project to interview young 
kibbutz members who had fought in the Six-Day War. Transcripts of these interviews were published in a book titled Siah lohamim (Discourse of the Warriors), which was widely read at that time. ${ }^{29}$ Muki Tsur observes that in the course of conducting these interviews, they discovered "a crisis and a spiritual turning point" in their generation, as demonstrated by the agonized responses to war of the soldiers with whom they met, which stood in stark contrast to the celebratory atmosphere that was dominating Israel at the time..$^{30}$ "The newspapers and victory volumes, the ecstatic hikes in the conquered territories, the euphoria that broke out after the deep fears during the period of waiting [before the war] were not compatible with what we revealed," writes Tsur about himself and the others who interviewed these soldiers. ${ }^{31}$

Much inspiration for Hug Shedemot's cultural revolution of return to post-biblical Jewish sources came from the writings of the Zionist intellectual leaders and writers of the early twentieth-century wave of immigration to the Land of Israel, known as the Second Aliyah, including Yosef Hayyim Brenner, Aharon David Gordon, and Berl Katznelson. It was the ongoing relationship of these figures to the Jewish tradition that provided a model for members of Hug Shedemot of how they could find a path to that cultural heritage. As Gad Ofaz observes, while it is true that these Second Aliyah figures rebelled against the religious Diaspora culture in which they were raised, their relationship to Jewish tradition was more nuanced than that of the generation immediately preceding that of Hug Shedemot. ${ }^{32}$ When members of Hug Shedemot began to explore "the inner life of these [Second Aliyah] pioneers by means of their personal writings-diaries, letters, conversations-[they uncovered] the complexity of a push-pull relationship [with the Jewish tradition], a drive to cut themselves off combined with longings for the Diaspora home and its culture, study, prayer, [and] community relations." ${ }^{33}$ Yariv Ben-Aharon recalls that he and his peers were taught only about the rebellion against tradition of these earlier ideological and cultural leaders. However, after he began to explore post-biblical Jewish texts, BenAharon set out to challenge that mistaken notion and to assert that "these leading figures were experts in the language of the sources, made use of it, and depended on it." ${ }^{34}$ Indeed, he recalls, he realized later in life that he had never fully understood their writings until he had studied the traditional sources to which they referred.

Muki Tsur has written that a key discovery of members of Hug Shedemot in their attempt to reconnect with post-biblical Jewish texts was that throughout Jewish history, each generation has reinterpreted 
past sources to make them relevant. This process, they came to realize, is central to rabbinic Midrash, but is also present in the "midrashic" way members of the Second Aliyah recast Jewish concepts as applicable to modern Zionism. Tsur declares that just as earlier generations felt they had the "the right to interpret" (hazekhut lidrosh), so too did members of his own generation. The declaration of this right, according to Tsur, has made it possible for them to "accept the yoke of the tradition, but we see for ourselves the right and the ability to express our world by means of it; there is in the right to interpret a recognition of the eternity of the Torah and a recognition of the historical contexts of its manifestations .... There is in the right to interpret a recognition of the fact that the dream of one generation depends on the interpretations of another generation." 35

Berl Katznelson was one of the most outspoken Second Aliyah advocates of the importance of Zionists staying connected with the heritage of rabbinic Judaism. A representative example of his approach to this issue may be found in an essay he published in the Labor Zionist newspaper Davar in 1934, "Hurban utelishut" ("Destruction and Uprootedness"). In this essay, he wrote that it made him very uncomfortable to learn that a Zionist youth group went off to its summer camp on the night of Tisha B'Av, the fast commemorating the destructions of the First and Second Temples in Jerusalem, "the very night on which the people of Israel laments its destruction, its enslavement, and the bitterness of its exile," as he put it. ${ }^{36}$ The youth group's disassociation from this fast day was, for Katznelson, a most unfortunate instance of the tendency of secular Zionists to distance themselves from all that is associated with the vulnerability of Jewish Diaspora existence.

In an article he wrote shortly afterward, "Meqorot lo-akhzav" ("Reliable Sources"), Katznelson made clear why he was so disappointed in what he saw as the youth group's desecration of Tisha B'Av. "A generation that renews and creates," he declared, "does not throw on the trash heap the inheritance of past generations. ${ }^{37}$ Instead, Katznelson asserted, a truly creative generation "sometimes grabs on to existing tradition and adds to it; sometimes it descends to the junk pile, uncovers that which was forgotten, polishes off its rust, and revises an ancient tradition which has the ability to nourish the soul of the renewing generation." ${ }^{38}$ Indeed, he asked rhetorically, "If there is in the life of the people something that is very ancient and very deep, that has the ability to educate people and to strengthen them for the future, would it be appropriate for revolutionaries to reject it?"39 
Once their curiosity about the post-biblical tradition from which they had been deprived was aroused, the challenge facing the members of Hug Shedemot was how to make up for their lack of education in post-biblical Jewish texts and thereby gain access to them. For the most part, they did not seek to be taught these texts by rabbis fully versed in post-biblical Judaism. Instead, members of Hug Shedemot turned to academics of European origin at the Hebrew University, including such figures as Shmuel Hugo Bergman, Martin Buber, Nathan Rotenstreich, Gershom Scholem, and Ernst Simon, who could serve as models of how to study traditional Jewish texts from a modern perspective. ${ }^{40}$ Gad Ofaz notes that these scholars served well the need of secular kibbutz members to explore post-biblical Jewish sources because, as he puts it, "in their thinking and writings they combined the traditional Jewish sources with modern culture and thought." ${ }^{41}$ Muki Tsur writes that the fact that these scholars were conscious of the "spiritual void" of the breakdown of religious faith in the modern period made them more appropriate teachers of Judaism for Hug Shedemot than traditional rabbinic scholars unwilling to acknowledge the contemporary spiritual crisis of Judaism. ${ }^{42}$ In addition, Avraham Shapira developed a close relationship with the intellectually open faculty of the Jewish Theological Seminary of the Conservative Movement in the U.S, and as a result they served members of Hug Shedemot as another source of access to traditional Jewish texts. ${ }^{43}$ Eliezer Schweid, a native-born Israeli, the son of parents who arrived in the Land of Israel during the Third Aliyah, had spent a period of time as a young adult as a member of a kibbutz, during which he published articles in the journal Shedemot. After completing a doctorate in Jewish studies at the Hebrew University in 1963, he joined the faculty of that university and thereby became an important role model for members of Hug Shedemot seeking to engage in the study of Judaism. In 1984, for example, Avraham Shapira received a Ph.D. at Tel Aviv University based on his doctoral thesis on the writings of Martin Buber.

Secular kibbutz members who sought to return to the Jewish bookcase also gained knowledge of the post-biblical Jewish tradition from older kibbutz members who had come as young men to Israel after having studied in yeshiva in Europe. One important example of such a figure was Meir Ayali (1913-2001), who had attended yeshiva and university in Europe before emigrating to the Land of Israel in 1934. Ayali was deeply concerned about the tendency of members of his generation to 
dismiss the Jewish post-biblical textual tradition, and he devoted himself to increasing knowledge of that tradition among his fellow kibbutzniks. In 1971, he wrote that he feared that one day kibbutz culture would be based only on the Bible, with no reference to rabbinic texts. He dreaded the loss to Israeli Jewish culture if, in his words, "the entire connection to Jewish values will be solely based on the Bible ... skipping over all that was created in the intervening periods and ignoring it." 44

Ayali insisted that "the Bible is not what distinguishes Jewish culture from other cultures and it did not in itself determine the character of Judaism." ${ }^{45}$ What became Judaism, he argued, was based on "the interpretation [of the Bible] that the sages of the generations presented, the spiritual and practical meanings that were concluded from them." ${ }^{46}$ He believed that it would be culturally disastrous if kibbutzniks did not learn about the ways that rabbinic interpretations of the Bible moved Judaism in a more humanistic direction, adjusting the original biblical meanings to reflect contemporary perspectives and concerns.

In keeping with his conviction of the importance of engaging in the full range of the traditional Jewish heritage, Ayali studied with a number of the leading scholars of Jewish studies at the Hebrew University, and he completed a doctoral dissertation at the Hebrew University under the direction of Ephraim Urbach, titled "The Status of the Hired Worker in the Talmud," in which he combined his socialist commitments with his intense interest in rabbinics. ${ }^{47} \mathrm{He}$ also published works of scholarship on post-biblical texts, including the Talmud and Responsa literature, and he was the founding editor of a series of books in Jewish studies, Helal Ben-Hayim, issued by the kibbutz-sponsored publishing house Hakibbutz Hameuchad. ${ }^{48}$

As an educator, Ayali encouraged kibbutzniks to study the post-biblical textual tradition. When he was principal of a regional kibbutz high school, for example, he organized a voluntary Talmud study group for students. In 1966, at Kibbutz Yifat, he established what appears to have been the first all-night Shavuot study session (tiqqun leyl shavu'ot) for secular Israelis. This tradition continued throughout his life and was eventually widely adopted throughout the country by secular Israelis seeking to participate in the return to the Jewish bookcase. ${ }^{49}$

In establishing the Shavuot study session, Ayali radically challenged the attempt of the secular kibbutz movement to revive the biblical agricultural dimension of the holiday, the bringing of the first fruits, at 
the expense of the meaning the rabbis had attributed to the holiday as a commemoration of the giving of the Torah at Mount Sinai.

In 1968, Ayali wrote about why he opposed the way that secular kibbutzim observed Shavuot: "Out of an honest and enthusiastic desire to renew the youthful period of the nation, we [kibbutzniks] chose to restore the original agricultural dimension and the return to nature, but out of an exaggerated zealousness 'to return to the sources' we threw out the spiritual dimension that had aroused soulful contemplation and the experience of holiness." ${ }^{50}$ In effect, he explained, the secular kibbutzim reversed the process in which the rabbis had moved the holiday away from being "a primitive cultic holiday." ${ }^{51}$ He noted that he experienced anxiety every year when he witnessed an older kibbutznik symbolically "sacrificing the first fruits to the Jewish National Fund, following which our beautiful daughters go out in a charming dance of thanksgiving, as if they were priestesses of [the pagan god] Baal ...." ${ }^{52}$ He simply could not understand why his fellow kibbutzniks were not aware "of the danger that by exaggerating the natural dimension and eliminating the spiritual meaning, we are returning to a primitive paganism, the enemy of culture, even if only in a symbolic manner." ${ }^{33}$

David Zimmerman (1911-1984), a contemporary of Meir Ayali, was a yeshiva-educated European Jew who emigrated to Israel in 1935 and became a member of two secular kibbutzim in the course of his adult life: Na'an and Mishmar Hasharon. David Zimmerman's son Be'eri, a teacher in institutions devoted to the return to the Jewish bookcase, told me in an interview that his father was part of what Be'eri called an "underground" of fellow former yeshiva students living in secular kibbutzim who maintained an active interest in rabbinic literature, quietly defying the dominant anti-rabbinic ethos of secular Zionism. During our interview, Be'eri proudly pointed to the full set of the Babylonian Talmud that he had inherited from his late father and fondly recalled how, as a small child, he had been very impressed by the large volumes of the set placed on the bottom shelf of the bookcase, which were taller than he was. David Zimmerman taught kibbutzniks selections of rabbinic legends, and he began publishing such legends with interpretive comments in the journal Shedemot.

Eventually, the appeal of post-biblical Jewish texts spread considerably beyond the secular kibbutzim, and since the late 1980s, study houses devoted to drawing secular Israelis to these texts have been established to provide an institutional framework for satisfying the need of secular 
Israelis to discover these repressed elements of their culture. The most influential of such institutions, sometimes referred to as "pluralistic study houses," include two which grew out of earlier programs of Jewish studies initiated by members of Hug Shedemot, Hamidrashah Be'Oranim in Kiryat Tivon, and Beit Hamidrash Bina in Ramat Efal. Other important pluralistic study houses are Elul in Jerusalem, Alma in Tel Aviv, Kolot in Jerusalem, Ein Prat-Hamidrashah Be'Alon near Jerusalem, and three secular yeshivot established by Bina, in Tel Aviv, Jerusalem, and Beersheva. Additionally, among the pre-army year programs available to high school graduates, a number are devoted to introducing secular Israelis to the study of traditional Jewish texts. Midreshet, an umbrella organization of pluralistic study houses, has a web site which offers source sheets with discussion questions that can be used by anyone engaged in the study of traditional Jewish texts. ${ }^{54}$ Other popular manifestations of the study of traditional Jewish texts are the annual festival of study Lo Bashamayim at Kfar Blum in the summer and the study conference Hakhel in Jerusalem during Sukkot, which is organized by Panim, an umbrella organization for groups devoted to new approaches to Judaism in Israel..$^{55}$

One of the most important developments that facilitated the study of Talmud among secular Israelis was the project undertaken by Adin Steinsaltz from 1965 to 2010 to publish a new edition of the Babylonian Talmud with a vocalized text, all of its Aramaic passages translated into Hebrew, and explanatory notes. This edition, designed to make the Talmud accessible to those without a yeshiva education, is the one generally used for the study of Talmud in the pluralistic study houses and other non-yeshiva settings. Ruth Calderon, who as a secular Israeli studied traditional Jewish texts at Hamidrashah Be'Oranim and at the Hebrew University and eventually was involved in the founding of both Elul (together with Mordechai Bar-Or) and Alma, has testified that, "If the Steinsaltz edition of the Talmud had not been created during the period I was growing up, I would not have been able to study [Talmud] at all. Not only I, but all of the [participants in the pluralistic] study houses have been dependent on it." 56

Calderon has explained that she began to explore post-biblical Jewish texts because she found that she identified with them more than she did with the Bible itself. She found herself drawn to the radical reinterpretation of the Bible in rabbinic Judaism, in which priests were replaced by sages, location in one territory was replaced by location anywhere, and sacrifices were replaced by prayer and study. ${ }^{57}$ The Bible, she argues, served well 
the focus of Zionism on the assertion of Jewish power and territorial sovereignty in the Land of Israel, but she and others of her generation needed post-biblical Judaism to provide them with the path that they sought to "compassion, humility, [and] delicacy, which did not have a place in [Zionist culture]." ${ }^{8}$ This was particularly true, Calderon relates, in the aftermath of both the Six-Day War and the Yom Kippur War. "[Both wars]," she argues, "taught the Israeli public ... that [they] did not bear enough memory in order to build an Israeli culture that could come to terms with such challenges as conquering and victory, the crisis of leadership, and the bitterness of war. Hebrew consciousness needed to recognize itself as part of a much longer process. The comfort, the prayer, the long and patient Jewish dream were needed so that the Jewish community in Israel would awake from its pridefulness and its pain, recognize itself anew, and continue to build itself." 59

Calderon attributes the growing interest in post-biblical Jewish texts among secular Israelis in part to similarities between the historical experiences of the Jews in the rabbinic period and those of contemporary Israeli Jews. Both, she notes, have lived in the aftermath of national tragedy-the destruction of the Second Temple and the Holocaust respectively. The experience of the rabbis, that the Jewish people had been abandoned by God when the Temple was destroyed, led them to think of God's involvement in human existence as much more limited than had been reported in the Bible. Contemporary Israelis who doubt that God plays a role in history and may even doubt His actual existence as a result of the Holocaust, she argues, could therefore identify more with the rabbinic view of a God less involved in the world than with the biblical view of a God who regularly intervenes in human affairs.

Furthermore, Calderon observes, as opposed to the Israelites' experience in the biblical world, in which people received revelations of absolute truths by prophets, the rabbis no longer counted on the possibility of a divine revelation to human beings. Instead, they turned to human deliberation on how to understand sacred texts in order to decide how they should live their lives. Calderon cites the moment in the Talmudic story "The Oven of Akhnai" when Rabbi Yehoshua stands up to God and refuses to make a legal ruling according to a voice from Heaven that supported the position of his opponent Rabbi Eliezer. In this statement, argues Calderon, Rabbi Yehoshua makes clear that " $[\mathrm{t}]$ ruth [based on divine revelation] is no longer decisive, and perhaps there is no absolute truth ... and in a place of communal learning the 
process, the discussion, and the vote [provide] the only relevant truth," a notion that resonates with the post-modern skepticism of contemporary Israelis. ${ }^{60}$

Calderon also observes that when, in this story, God is portrayed as smiling in response to Rabbi Yehoshua's challenge to His authority, one finds a rabbinic view of God that differs radically from the view of God found in the Bible, which is potentially attractive to her contemporaries. "It is difficult to imagine the biblical God smiling," she observes, "Smiling is a delicate response and behind it is a complex personality. ... The biblical God rarely appears like this. The biblical God is a force of nature. He is the Creator of the world; He intervenes in it at His will with great gestures-the flood, the destruction of Sodom, the splitting of the Sea of Reeds. The smile testifies to a transition from the biblical image of God painted in oil colors ... to the Talmudic image of God, drawn in pencil and hints of water color with a delicate line." ${ }^{61}$ In addition, she suggests, the God in this rabbinic story is now prepared to turn much of His power over to human beings. "God ... is proud of His creatures who stand before him in maturity and not in submission," she observes. "God is impressed and proud of His creatures who create a world in which He does not have the possibility of intervening, like a father who rejoices in his son when he beats him in a game of chess." ${ }^{62}$ This, according to Calderon, is an image of divinity that is more appealing to contemporary Israelis with their anthropocentric humanistic worldview than that found in the Bible.

Calderon cites another reason why she and other secular Israelis who returned to the Jewish bookcase considered it to be of central importance to study rabbinic literature, especially the central text of that literature, the Talmud. As long as secular Israelis are ignorant of the Talmud, she argues, they will not have the ability to forge the kind of Jewish culture that best meets their needs and reflects their worldview. In effect, she declares, "the secular and pluralistic study [of Talmud] is a struggle for liberation [from the authority of the religious]," who claim an exclusive prerogative to define what Judaism is, based on their knowledge of the Talmud. ${ }^{63}$ It is only by knowing this text on which Jewish culture is based, she maintains, that secularists can "participate at all levels in the formation of our culture ... to live [our lives] as [Jews] in an authentic manner: to marry, to celebrate a Bar Mitzvah, to study, to create, and even to bury, God forbid, in an authentic manner" on their own terms. ${ }^{64}$ 
In the early years of the pluralistic study houses, many secularists resisted the notion that there was value in studying the post-biblical Jewish tradition. Yariv Ben-Aharon reports that when he declared that he wanted to commit himself to teaching traditional Jewish sources, members of his kibbutz "related to me a bit as if I were the village idiot." ${ }^{5}$ He goes on to recall that his father, Yitzhak Ben-Aharon, a leader of the kibbutz movement, "was never interested" in his pursuit of Jewish learning and teaching. ${ }^{66} \mathrm{He}$ surmises that this was because his engagement with the post-biblical Jewish tradition raised in his father's imagination the "images of rabbis and Hasidic rebbes whom he had known in Romania [before immigrating to the Land of Israel], with all of their superstitions." ${ }^{67}$

Muki Tsur recalls that when Avraham Shapira first introduced the study of traditional Jewish texts at the Kibbutz Seminar at Oranim, which eventually led to the creation of Hamidrashah Be'Oranim, the faculty members of the seminar were greatly concerned that "the coming out of the closet of Judaism could perhaps create a new orthodoxy and perhaps even bring about a return to traditional Jewish observance (hazarah beteshuvah) or insert cracks in the secular orthodoxy and bring harm to liberalism and socialism." ${ }^{68}$ Sara Shadmi-Wortman, an early leader of Hamidrashah Be'Oranim, writes of how challenging it was at first to disseminate the study of the Jewish tradition to secular Israelis. The teachers were forced to make efforts "to create a change in consciousness, to break the emotional barriers of the young secularist before his Jewish identity. The assumption was that these barriers are not just a matter of lack of knowledge, but also a deep alienation from the substance [of the identity] and a lack of a feeling of being at home in the Jewish tradition, stemming in part from the suspicion that opening up to it would obligate one to transform one's personality, to change one's way of life, and to become someone else." 69

Micah Goodman, founder of Ein Prat-Hamidrashah Be'Alon, has stated that he believes that the secular alienation from tradition with which leaders of the pluralistic study houses originally had to deal is less of a factor in today's Israeli youths. "Today," he explains, "there is a new generation [of Israelis] who are secure in their secular identity."70 Unlike members of previous generations, he claims, "they do not have to base [their secular identity] on a negation of Judaism." ${ }^{71}$ He reports that "many young secularists I meet say, 'I am a secularist who is connected to Judaism." 72 The current generation of young secularists, he notes, "[t]the descendants of those who rebelled against the tradition, have found that they have nothing against which to rebel. The grandparents and parents 
of the current generation sought to liberate themselves from the heavy yoke of the Jewish tradition that limited their personal growth, while today, after there is nothing left of this tradition, the current generation is seeking a tradition that will help them to grow in new areas." ${ }^{73}$

At times, the pluralistic study house movement has aspired to overcome the social, cultural, and political barriers between secular and religious Israelis. One of the goals of Elul, when it was first founded by the secular Ruth Calderon and the religious Mordechai Bar-Or, was to attempt to break down those barriers by creating a space in which secular and religious Israelis could study traditional texts together. As Ruth Calderon recalls, their hope was to replace the typical model of religious-secular learning in which the secular Israeli comes to the religious Israeli to learn traditional texts from him. They wanted what Calderon refers to as "an egalitarian learning" in which the secular and religious Israelis would engage together in the study process. ${ }^{74}$

Following the assassination of Prime Minister Yitzhak Rabin in 1995 by a religious Zionist, a political conflict erupted between secular and religious Israelis. Secular Israelis accused religious Israelis and the Jewish texts they studied as being responsible for this national tragedy. Bina was founded shortly after the assassination in part as an attempt to address the emergence of this secular alienation from religious Israelis and from the Jewish tradition, as a result of which, in the words of Bina's founder and director, Eran Baruch, "many Israelis refrained from touching what was perceived as religious or ultra-Orthodox and felt this was not theirs." ${ }^{175}$

Some pluralistic study houses have begun to explore how the study of post-biblical Jewish texts can contribute to efforts to improve Israeli society. At the secular yeshivot founded by Bina, students devote a considerable period of time during the week engaged in helping to improve the lives of residents in the city where their yeshiva is located. This turn to social action has given rise to an effort to complement the original emphasis of the pluralistic study houses on the study of rabbinic legendary texts (aggadah) with the study of rabbinic legal texts (halakhah). Mordechai Bar-Or, Head of Kolot, has argued that the Jewish tradition can change the way people in Israel conduct their lives for the better, but only if their study of that tradition includes the rabbinic legal texts that speak of what obligates a Jew. In keeping with this approach, the Kolot program Bar-Or designed is made available to professional leaders in such areas as economics, government, and the army who, he hopes, will bring the values reflected in traditional Jewish legal and legendary texts to their work and thereby make positive changes in the way Israeli society functions. ${ }^{76}$ 
Hamidrashah Be'Oranim has also moved in this direction. In 2013, it published a commentary on a Talmudic discussion of the laws designed to control male sexual desires and to channel them into their proper expression in marriage and related stories embedded in that discussion. ${ }^{77}$ This is the product of a group of women in a program called Niggun Nashim, who undertook what they call a feminist reading of this Talmudic discussion and a consideration of its relevance to the demand of some religious Israelis to enforce a greater separation between men and women in the public sphere, which has the effect of marginalizing the role of women in that sphere. ${ }^{78}$ The goal of this project was to open up discussion of this issue and arrive at a reasonable public policy that takes into account both the need for standards of sexual morality and the importance of allowing women equal participation in Israeli society. ${ }^{79}$

In the early 2000s, some secular Israelis involved in the return to the Jewish bookcase began to move beyond the mere study of traditional Jewish sources to the establishment of communities of secular Israelis that would, along with the study of traditional Jewish texts, undertake Jewish religious practice, including Sabbath and holiday celebrations, prayer services, life cycle events, and social action. Their practice draws on Jewish traditions and elements of modern Israeli culture and is not necessarily guided by traditional Jewish law. In 2000, Bini Talmi, Shay Zarchi, and Moshe Yitzhaki, instructors at Oranim, established a community named Nigun Halev, which meets in Moshav Nahalal in Emek Yizrael. ${ }^{80}$ Similar communities have been established throughout the country. ${ }^{81}$ One of the best known of these communities is Beit Tefilah Israeli, founded in Tel Aviv in $2004 .^{82}$ That community organizes a Kabbalat Shabbat service by the Mediterranean port of Jaffa on Friday evenings in the summer. ${ }^{83}$

\section{Religious Israelis Rediscover Rabbinic Legends}

Religious Israelis had no need to "return to the Jewish bookcase," during the second half of the twentieth century because they had never left it. The post-biblical Jewish textual tradition that had been largely marginalized in secular Israeli culture has played a central role in the culture of religious Israelis, as it did for generations of Jews. Nevertheless, one genre of post-biblical Jewish texts, that of rabbinic legends (aggadah), found in the Babylonian Talmud, the Jerusalem Talmud, and midrashic 
collections, was not always taken seriously in the culture of religious Jews in the Diaspora.

Yair Lorberbaum argues that early rabbinic literature was characterized by an integrated approach to halakhah and aggadah, with both genres viewed as valuable sources of religious truth. "The Mishnah," he writes, "freely intertwines halakhah and aggadah, drawing no distinction between the two; the same holds true with respect to midreshei halakhah and the Tosefta. The Babylonian Talmud abounds with challenges to the aggadah, while relying upon it in halakhic matters." ${ }^{\text {" It }}$ was during the post-Talmudic Geonic period, he observes, that some religious scholars began to make a clear distinction between halakhah and aggadah and to assert that aggadah was not a reliable source of religious knowledge, especially when it came to the all-important challenge of determining Jewish law. Lorberbaum captures this approach in a statement by Rabbi Hai Gaon (939-1038):

It should be known that the words of aggadah do not have the status of oral tradition, and each person conjectures as he pleases, employing such terms as "perhaps" and "it could be said," so that the issues are not clearly defined. For that reason we cannot rely upon them.... And these midrashot are not tradition and not halakhah, but were only stated by way of conjecture (Otsar Hage'onim, Hagigah, Commentaries Section 14a). ${ }^{85}$

As Lorberbaum notes, some rabbinic scholars followed this trend to isolate aggadah from halakhah and to denigrate its value, while others "adhered to the Talmudic tradition, viewing aggadah as an authoritative source and as a subject for study and extrapolation." ${ }^{86}$

In Eastern Europe, where the majority of religious Zionist immigrants to the Land of Israel were born, rabbinic legends primarily played a role in the more popular religious culture. Less learned Jews found in rabbinic sermons drawing on legends or in the direct study of legendary texts a spiritual sustenance that was not available to them from the legal texts more central to the yeshiva curriculum, which they found difficult to understand. In Eastern European yeshivot, following the approach introduced in the Geonic period, legendary texts (aggadah) were viewed as much less significant than legal texts (halakhah), and it was typical for those learning in the yeshivot to skip over legendary passages in the Talmud. The late nineteenth and early twentieth-century Hebrew writer Micha Yosef Berdyczewski 
recalls this disdain for legends in his fellow yeshiva students: "I heard with my own ears from the highest ranked students of the yeshiva, who think that the whole world was created only for them, saying, 'If we printed [the Talmud], we would skip the legends and not print them at all, because of what use are they? Legends were only created for the simple people ... but not for us."'87

Rav Avraham Yitzhak Kook (1865-1935), the spiritual father of religious Zionism, strongly argued that aggadah was as religiously significant as halakhah. In a diary entry Kook wrote in the early twentieth century, he asserted his belief in the important religious value of legendary texts, and he argued for a method of Talmud study in which both legal and legendary passages would be taken with equal seriousness: "Legal and legendary texts must be unified together. The need to study them together of necessity will also bring about their spiritual unity" ${ }^{88}$ In keeping with his general philosophical quest for that which unites opposites (ahdut hahafakhim), Rav Kook argued here that his advocacy of integrating the study of legal texts and the study of legendary texts was not his own invention, that they are actually deeply intertwined. "This joining together," he wrote, "is nothing less than the revelation of the unity hidden within them that has always existed." 89 Rav Kook signaled the importance he saw in legendary texts by writing a partial commentary to Eyn Ya'akov, a compilation of legends found in the Babylonian Talmud. ${ }^{90}$

Rav Kook's attempt to raise the status of legendary texts had little impact on those engaged in the highest levels of traditional study in the yeshivot of his day, and the longstanding neglect of aggadah has persisted in most Israeli yeshivot until the present. As recently as 2009, Binyamin Kelmanson, Co-Head of Yeshivat Otniel, lamented the fact that even as religious Zionist yeshivot have engaged in revising the curriculum of study to supplement the centrality of the study of the legal passages in the Talmud, "aggadah is still neglected."11 He made this statement in the Introduction to a book based on classes he taught at his yeshiva in which he engaged in a detailed analysis of rabbinic legends about the destruction of the Second Temple in Jerusalem, thereby challenging the trend in yeshivot to refrain from engaging in any serious way with aggadah. There are other signs of a trend among religious Israelis to value the study of legendary rabbinic texts. In 2006, Galei Masekhta, a religious study house devoted to aggadah, was established in Jerusalem and later became associated with Yeshivat Yafo. Since 2009, Yeshivat Ahavat Yisrael in Netivot, which is committed to the 
inclusion of aggadah in its curriculum, has held an annual day devoted to the study of aggadah, and the papers presented at that event are published in a journal titled Asuppot. In addition, the religious Zionist Mikhlelet Efrata in Jerusalem has an Aggadah Teaching Center and publishes a journal of studies on rabbinic legends, Derekh aggadah.

Contemporary religious Israelis advocating a return to aggadah have found inspiration in the insistence of Rav Kook that Jewish study could be complete only if both halakhah and aggadah were studied in tandem with teach other. They are particularly taken by Rav Kook's notion that the integration of halakhah and aggadah would be a central characteristic of the way Torah would be studied in the Land of Israel, referred to by many as torat erets yisra'el. In its programmatic founding statement, Galei Masekhta states clearly that their approach directly follows Rav Kook's “call for a general renewal of Torah study, at the center of which is the systematic and deep study of aggadah, which he considered to be the key to a transition from the Torah of the Diaspora to the Torah of the Land of Israel-a Torah that would be the fountain and heart of the culture of the people of Israel returning to its Land."92

Religious Zionist rabbi and Talmudic scholar Yehuda Brandes published a two-volume series, Aggadah lema'aseh $(2005,2011)$, in which, in the spirit of Rav Kook's teachings, he sought to counter the tendency in the yeshiva world to denigrate the value of studying legendary passages in favor of the study of legal passages in the Talmud. In the Introduction to the first volume he challenges the accepted notion that law and legend play two distinct functions. "The separation of aggadah from halakhah," he writes, "is an impossible task..93 Instead, he argues, legend plays an indispensable role in the rabbis' legal discussions of how one should act in life. Legal texts, he suggests, cannot adequately teach all that one needs to know to understand how to live. "Legend completes what is missing [in the legal text] with spiritual and ideational contexts and provides people of the law-sages, legal decisors, teachers of law, and also the simple person obeying the law-the overview and the depths of consciousness that will guide their teachings, decisions, and actions in order that they will not miss the correct path of the law and become lost in the thicket of details." ${ }^{\text {"94 }}$ Such an understanding of the spirit of the law that legend presents is particularly needed, Brandes observes, "especially in legal topics in which it is necessary to bring to bear human sensitivity beyond the letter of the law. ${ }^{15}$ In the two volumes, Brandes analyzes selected Talmudic passages in which law and legend are intertwined and legend serves to deepen one's understanding of the complexities of the law. From time to time, Brandes 
steps away from his textual analysis to suggest how the Talmudic passages may have something to say about contemporary issues. ${ }^{96}$

Religious Zionist rabbi Binyamin Lau has also made an important contribution to the revival of interest in rabbinic legends among Israelis. During the years 2006-2012, he published a four-volume series, Hakhamim, in which he drew on Talmudic stories and reported sayings of the ancient rabbis to write a history of how rabbinic Judaism developed. Hakhamim began in a traditional Jewish context, a series of talks Lau gave in his synagogue about the Talmudic tractate Pirkei Avot, which he delivered beginning in the summer of 2004 in the afternoon of the Sabbath when it is customary to read from that tractate. In subsequent years, he drew increasingly on the whole range of Talmudic stories, and periodically he would transform his talks into the volumes that became part of the series.

Lau writes in the Preface to the first volume that he aspired in the work to synthesize between the traditional yeshiva approach to Jewish texts and that of modern academia, taking into account both the religious teachings of the stories about the sages and the historical contexts in which the sages functioned. ${ }^{97}$ Lau sees these stories as dealing with larger religious issues that could be of relevance to contemporary readers. "It is my prayer," he writes, "that the results of this study will draw us nearer to the world of the sages and by understanding their world we will better understand our world and improve it." ${ }^{98}$ Indeed, in the earlier volumes of the series, he interrupts the flow of the historical narrative to comment on how one can find contemporary religious lessons in the lives and thought of the rabbis.

Aggadah is the genre of rabbinic literature that has most appealed to secular Israelis returning to the Jewish bookcase, largely due to the fact that the narratives of rabbinic legends are more accessible to them than the more complex and specialized legal discussions of halakhah. And so, as religious Israelis have begun to reevaluate the significance of aggadah, these two cultural groups' interests have converged. These interests meet in particular in the subgenre of aggadah, the Talmudic story, of which the story about Rabbi Rahumi and his wife, cited by Ruth Calderon in her Knesset speech, is a prime example. Indeed, as we follow Israeli interest in Talmudic stories and the interpretations of those stories by contemporary Israeli readers, we will discover a wide range of secular and religious readers engaged in what amounts to the same project: the cultural re-appropriation of a neglected but valuable resource and the attempt to understand that resource in terms of contemporary perspectives and concerns. 